\title{
Máshonnan tekinteni a posztszocialista városokra? Beszámoló a Cities After Transition hálózat 2017-es konferenciájáról
}

\author{
A view on post-socialist cities from elsewhere? Report \\ on the 2017 conference of the Cities After Transition \\ network
}

BERKI MÁRTON

BERKI Márton: egyetemi adjunktus, Eötvös Loránd Tudományegyetem, Természettudományi Kar, Földrajz- és Földtudományi Intézet, Társadalom- és Gazdaságöldrajzi Tanszék; 1117 Budapest, Pázmány Péter sétány 1/C.; berkimarton@yahoo.com; https://orcid.org/00000002-0727-1212

\begin{abstract}
Márton BERKI: senior lecturer, Department of Social and Economic Geography, Institute of Geography and Earth Sciences, Faculty of Science, Eötvös Loránd University; Pázmány Péter sétány 1/C., H-1117 Budapest, Hungary; berkimarton@yahoo.com; https://orcid.org/0000-0002-07271212
\end{abstract}

A posztszocialista városokkal foglalkozó kutatókat tömörítő Cities After Transition (CAT) hálózat kétévente szervezett konferenciája, az ún. CATference a témakör legnagyobb szabású eseménye, amely első alkalommal Lund városában (2005), majd ezt követően Stockholmban és Tallinnban (2007), Tartuban (2009), Bukarestben (2011), Tbilisziben (2013) és Prágában (2015) került megrendezésre. A 2017. szeptember 26-29. között Ukrajnában zajló esemény egyik különlegességét az adta, hogy a konferenciaprogramra két - egymástól légvonalban is közel 400 km-re fekvő - városban, egymást követően került sor. Az első két nap helyszíne a kijevi Taras Shevchenko National University volt, míg a harmadik nap szekció-előadásai már Dnyipróban (a korábbi Dnyipropetrovszkban), a Menorah Center kulturális és üzleti központban zajlottak. A CATference-ek esetében hagyománynak számít, hogy az előadásokat egész napos terepi alkalom követi, melynek célállomása ezúttal „Ukrajna vasszíve”, Krivij Rih városa volt. (Emellett azonban számos egyéb szakmai program, például helyi kutatók által vezetett tematikus városi séták is értékesebbé tették a programot.) A konferencia a kijevi Taras Shevchenko National University, a dniprói Oles Honchar National University, a University of Oslo, a Ukrainian Geographical Society, a Ukrainian Researchers Society civil szervezet,

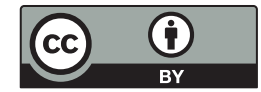


valamint a 2017-ben éppen 40 éve alapított IJURR (International Journal of Urban and Regional Research) folyóirat közös szervezésében valósult meg.

A hivatalosan 7th International Urban Geographies of Post-Communist States Conference elnevezésű esemény tematikus alcíme ezúttal „A view on cities from elsewhere”, vagyis „Máshonnan tekinteni a városokra” volt. Ez nyilvánvaló utalás az ún. összehasonlító városkutatás (comparative urbanism) megközelítésére, amelynek deklarált célja a városokkal kapcsolatos tudástermelés központjának kimozdítása a „globális Északról”, azaz a városkutatási diszciplínát a kezdetek óta uraló nyugati elméletek dominanciájának megtörése. A posztkolonialista hagyományból táplálkozó megközelítés képviselői (McFarlane 2010; Robinson 2006, 2011, 2015; Roy 2009 stb.) szerint kiemelten fontos a Nyugat-Európa és ÉszakAmerika paradigmatikus városain túli tapasztalatok figyelembevétele (s ezáltal a városelméletek dekolonializációja és pluralizálása), ugyanis a globális perifériák és félperifériák városi folyamatai nem egyszerüen „egzotikus” empirikus változatok, a nyugati jelenségek és folyamatok helyi példái vagy ellenpéldái. Arra a felismerésre, mely szerint a megértés és az elméletalkotás szempontjából lényegében bármelyik város fontos lehet (Robinson 2006), közel egy évtizedig szinte egyáltalán nem reagáltak a posztszocialista városokkal foglalkozó kutatók. Ennek eredményeként az elmúlt években széles körben csupán elszigetelt „térségtanulmányoknak” (Grubbauer, Kusiak 2012, 14.), „elmaradottnak” (Ferenčuhová 2012, 65.), sőt, egyenesen „láthatatlannak”, „súlytalannak” (Sjöberg 2014, 299.) titulálták a posztszocialista városkutatást, amelyben mindössze a közelmúltban jelentek meg az összehasonlító városkutatás vizsgálati szempontjai (lásd Tuvikene 2016 úttörő kísérletében). A CAT-hálózat esetében ez a törekvés már a legutóbbi, 2015-ös prágai konferencián is megfogalmazódott, elsősorban Jennifer Robinson (University College London) plenáris előadásában, majd ennek tanulmány formájában megjelent változatában (Robinson 2016). Annak ellenére azonban, hogy a 2017-es esemény alcímében és konferenciafelhívásában is kiemelt helyen szerepelt az összehasonlító városkutatás gondolatisága és az arra történő reflexiók szükségessége, néhány előadást leszámítva végül nem bizonyult hangsúlyosnak ez a megközelítés. (A beküldött és közzétett absztraktok, valamint a recenzens helyi tapasztalatai alapján mindössze néhány előadó reflektált a felhívás e részére.)

A konferencia rövid, lényegre törő megnyitója után Vlad Mykhnenko (University of Oxford) plenáris előadása hangzott el, melyben arra a látszólagos ellentmondásra hívta fel a figyelmet, hogy a példátlan ütemű kínai urbanizáció mellett egyre több olyan térség is található az országban, amelyeket a városi zsugorodás (urban shrinkage) folyamata jellemez (a témáról újabban lásd Yang, Dunford 2018 tanulmányát). Ezt követően kezdetüket vették a szekció-előadások, nagyszámú és széles diszciplináris hátterü kutató részvételével, a plenáris és záró előadásokon kívül ugyanis 25 szekcióban 88 előadótól - valamint hozzájuk kapcsolódóan számos további társszerző munkája révén - hangzottak el előadások. Az első nap késő délutánján újabb három plenáris előadásra került sor, az IJURR folyóirat szponzorálásával: elsőként Hyun Bang Shin (London School of Economics), 
majd Joanna Kusiak (University of Vienna, Academy of Fine Arts in Warsaw), végül pedig Liviu Chelcea (University of Bucharest) adott áttekintést a posztszocialista városok és a dzsentrifikációkutatás kapcsolatáról, aktuális kérdéseiről és dilemmáiról. (A rövid korreferátumok felvezetője, valamint az azokat követő kerekasztal-beszélgetés moderátora Matthias Bernt, a Leibniz Institute for Research on Society and Space kutatója volt.)

A konferencia szekciói a korábbi CATference-ekhez hasonlóan ezúttal is a témák széles spektrumát fogták át. A két kijevi nap szekciói körüljárták többek között a posztszocialista átmenet értelmezésének elméleti vonatkozásait, ennél kissé szűkebben a kelet-közép-európai térség városainak helyét a kortárs városelméletekben, tágabban pedig a teljes „globális Kelet” elméleti (valamint társadalmi, mobilitási, gazdaságföldrajzi stb.) kérdéseit. Ezek mellett foglalkoztak a posztszocialista városok fizikai átalakulásával, a dzsentrifikáció aktoraival és helyszíneivel, a nagyvárostérségek mobilitási és ingázási kérdéseivel, a közösségi közlekedés hatékony kormányzásával és városi gyakorlataival, a szocialista lakótelepek kihívásaival (és az azokra adható tervezési és szakpolitikai válaszokkal), a lokális emlékezetpolitikával, az etnicitással, a városi „kreativitás” diskurzusaival (s ezen keresztül a földrajzi tudástermelés politikáival) vagy a tőke és a korrupció szerepével az európai posztszovjet térségben. A Dnyipróban rendezett, ugyancsak szerteágazó szekciók központi témái többek között a geopolitikai „törésvonalakon” fekvo városok identitás- és emlékezetpolitikai kérdései, az erősödő térbeni-társadalmi egyenlőtlenségek, a posztszocialista városok fenntarthatósági/smart/zöld(ítő) szakpolitikái, a kelet-közép-európai várostervezés aktualitásai és a kortárs kulturális városrehabilitáció kérdései voltak.

Még ha nem is kimondottan az összehasonlító városkutatás gondolatiságára támaszkodva, ám ez a tematikus sokszínűség beváltotta a szervezőbizottság abbéli reményeit, hogy a konferencia a nemzetközi városelméletre hatást gyakorló városok egyre növekvő „repertoárjába” helyezheti a posztszocialista városokat. Hogy ez milyen mértékben megy végbe és miben nyilvánul meg, arra részben a következő, 2019 őszén Belgrádban megrendezendő CATference szolgáltathat válaszokat - a 2017-es ukrajnai eseményhez hasonlóan remélhetőleg ezúttal is számos magyarországi előadóval.

\section{Köszönetnyilvánítás}

A konferenciabeszámoló a K 124291 számú, A poszt-szovjet után (?): A változó kelet-európai pufferzóna társadalmi folyamatainak földrajzi vizsgálata címủ projekt keretében, a Nemzeti Kutatási, Fejlesztési és Innovációs Hivatal (NKFIH) támogatásával készült. Elkészültét emellett az ELTE Felsőoktatási Intézményi Kiválósági Program (1783-3/2018/FEKUTSRAT) keretében az Emberi Erőforrások Minisztériuma is támogatta. 


\section{Irodalom}

Ferenčuhová, S. (2012): Urban theory beyond the "East/West divide"? Cities and urban research in post-socialist Europe. In: Edensor, T., Jayne, M. (eds.): Urban theory beyond the West: A world of cities. Routledge, London, 65-74.

Grubbauer, M., Kusiak, J. (2012): Introduction: Chasing Warsaw. In: Grubbauer, M., Kusiak, J. (eds.): Chasing Warsaw: Socio-material dynamics of urban change since 1990. Campus Verlag, Frankfurt, New York, 9-24.

McFarlane, C. (2010): The comparative city: Knowledge, learning, urbanism. International Journal of Urban and Regional Research, 4., 725-742. http://doi.org/bjgvcf

Robinson, J. (2006): Ordinary cities: Between modernity and development. Routledge, London

Robinson, J. (2011): Cities in a world of cities: The comparative gesture. International Journal of Urban and Regional Research, 1., 1-23. http://doi.org/bvhfvc

Robinson, J. (2015): Comparative urbanism: New geographies and cultures of theorizing the urban. International Journal of Urban and Regional Research, 1., 187-199. http://doi.org/cwdt

Robinson, J. (2016): Starting from anywhere, making connections: Globalizing urban theory. Eurasian Geography and Economics, 4-5., 643-657. http://doi.org/cwdv

Roy, A. (2009): The 21st century metropolis: New geographies of theory. Regional Studies, 6., 819-830. http://doi.org/cmnj8h

Sjöberg, Ö. (2014): Cases onto themselves? Theory and research on ex-socialist urban environments. Geografie, 4., 299-319.

Tuvikene, T. (2016): Strategies for comparative urbanism: Post-socialism as a de-territorialized concept. International Journal of Urban and Regional Research, 1., 132-146. http://doi.org/f8wj3b

Yang, Z., Dunford, M. (2018): City shrinkage in China: Scalar processes of urban and hukou population losses. Regional Studies, 8., 1111-1121. http://doi.org/cwdw 